\title{
Insulin-Like Growth Factor-Binding Protein 2
}

National Cancer Institute

\section{Source}

National Cancer Institute. Insulin-Like Growth Factor-Binding Protein 2. NCI Thesaurus. Code C17506.

Insulin-like growth factor-binding protein 2 (325 aa, 35 kDa) is encoded by the human IGFBP2 gene. This protein is involved in the modulation of plasma half-life for and signaling by insulin-like growth factors. 